Third Millennium Leaders: Thinking AND Acting BOTH Locally and Globally

by Dr Tony Townsend

Chair of Educational Research, Policy and Practice

Department of Educational Studies

University of Glasgow 


\section{Third Millennium Leaders: Thinking AND Acting BOTH Locally and Globally Tony Townsend}

If you fail to honor your people,

They will fail to honor you;

It is said of a good leader that

When the work is done, the aim fulfilled,

The people will say, "We did this ourselves.

Lao Tzu

Introduction

Peter Drucker (1993, p. 1) argued:

Every few hundred years in western history there occurs a sharp transformation. We cross... a divide. Within a few short decades society rearranges itself, its world view; its basic values; its social and political structure; its arts; its key institutions. Fifty years later, there appears a new world...we are currently living through such a transformation.

It could be argued that Drucker is talking about a principle similar to that of the S-curve, first discussed by Everett Rogers (1962) to describe the diffusion of innovations, where the S-curve described the number of people accepting an innovation over a period of time. New products or innovations were first accepted by a few 'early adopters', followed by the 'early majority', the 'late majority' and then the 'laggards'. Cumulatively, when graphed, the proportions of the population that have accepted the innovation over time form an S-curve. The underlying theory was later developed by a number of people (for instance, see Phillips, 2008) to look at how change, particularly in technology, progresses over time, and is a useful model for looking at how education has progressed over the course of history.

If we take a longer view of change in human learning we could argue that, since education first commenced, it has followed the S-Curve process. If we take a step backwards we can look at the progress made in education over the course of history. Then we can not only see the giant 
strides that have been taken in that time, but we can also see some trends that might help us to chart the way forward. For instance, it is possible to look at the progress of education in various ways. First, we might consider the focus of education at various times. This provides us with an understanding of the purpose of education and who was involved in its development and delivery. Second, education not only changed in terms of its focus, but also in terms of its scope. The scope of education provides us with an understanding of how far education reached in terms of its effectiveness and delivery.

I would argue that we have had four S-curves in education's history and that we are now on the verge of a fifth. The first, where the dominant drivers were individuals, lasted for more than four thousand years, the second saw the birth of local schools, and lasted for around eighty years, the third saw the intervention of national governments and lasted around twenty years and we are in about the $8^{\text {th }}$ or $9^{\text {th }}$ year of the fourth S-curve, where accountability systems and the market have become the dominant drivers of education. I will also argue that we are approaching the time where we need a new way of thinking about education, one that considers social justice issues at a global level.

If we look at education a thousand years ago, the focus was firmly on the individual as it had been since the dawn of time. Whatever formal education that existed was for the aristocracy, as a means of maintaining their position of power and privilege. Those who had the good fortune to be involved in education were being trained to be 'good' individuals with the hope and understanding that they would be leaders within a community of uneducated peasants. It could be argued that this was a society where some were 'born to rule.' Beare (1998: 4-5) describes this as the 'pre-industrial metaphor' for education. In terms of the scope of education, we could argue that, by the start of the second millennium, the education of the time had lasted for four or more thousand years, few people received any education at all and only a handful received what today might be considered to be an effective education. These conditions lasted until well into the 1870s. So the S-curve at this time was elongated over more than a couple of thousand years. 
Education became more accepted over time, but was never really institutionalized beyond small individual groups based on religion or power. It could be argued that at this point in history, when it came to education, we were thinking and acting individually.

In the 1850 s, community pressure was being exerted in many countries to provide a systematic education. Beare (1998: 5-6) calls this 'the industrial metaphor' where 'the factoryproduction metaphor [was] applied to schooling'. By the 1880s many developed countries around the world had created systems of education where the schools within a particular region were overseen by a local department or ministry.

So by 1900 , the focus of education had changed from the development of the individual to the development of local communities. Individuals were grouped into classrooms and classrooms were connected to form schools. Groups of schools served communities and became school systems. This phenomenon manifested itself in different ways, with state or provincial systems in some countries, school districts in other countries and local education authorities in others. The task of education was more than the development of individuals and was designed to consider and support whole communities, where people were placed in their rightful place in the community on the basis of the level of education they had obtained. The second S-curve had begun. Now we started thinking and acting locally. By the start of the 20th century, most people received some education, but only some received what today might be called an effective education. However, this focus and scope of education lasted for the best part of the twentieth century.

In the early part of the 1980 s, there was an emerging global economy, and technological development that changed the face of communication and knowledge exchange. Things changed quite dramatically in terms of the world balance of power. Western countries that had previously dominated the world economy and had been able to generate vast amounts of money by trading commodities such as food, wool and mineral resources to the underdeveloped countries in the East were now finding that these countries were able to use those commodities to manufacture products far cheaper than could the West, where hourly rates were up to twenty or thirty times 
higher. Countries such as the USA, the UK and Australia were now finding themselves spending more money importing goods that had been made using their exported commodities. Underlying this change in the world economic balance was the development and use of new technology that demanded a strong basic education for all people working in these industries. The new activity of measuring academic achievement internationally found that, in many instances, students in the high tech countries of the East were out-performing those in the West where factories and farms were still being utilized for those whose education was not sufficient.

Around this time, the focus of education shifted again, from the local to the national, as various countries in the West distributed reports, such as A Nation at Risk (National Commission on Excellence in Education, 1983) in the United States that linked the quality of education that students received to global economic supremacy, so the focus of education moved towards one that saw education as fulfilling national goals rather than providing for either the individual student or local communities. New terms echoed around the world; national goals, national curriculum, national standards and national testing, and became the watchwords for a new look education. Curricula were streamlined so that most time was spent on those areas that supported the national economic goals. Literacy, numeracy, vocational education and technology became the buzz-words of the decade and subjects not closely linked to the economy went into decline. Beare (1998: 9-13) described this as the 'post-industrial metaphor' where 'enterprise' became 'the favoured way of explaining how education operates'. Self-managing schools were developed in a number of countries, such as the United Kingdom, New Zealand, Australia, and Hong Kong and each school became a unit of work that was as successful as the work of the people in it. In order to improve national standing internationally, local schools became the focus of change. The third S-curve had begun. We were now thinking nationally and acting locally.

The scope of education also shifted. Governments and education systems argued that all students needed to succeed, but the evidence from national testing programs indicated that we were still falling short of that goal. However, as we approached the end of the 1990s we were able 
say that all people received a number of years of publicly supported education and that most of these students received a fairly effective education.

If we look at the dominant trends in our societies in the first decade of the third millennium, technology, the global economy, rapid international communication and the environment, among others, then these trends are international or global in nature. Now, economic problems in the USA create problems for people in other parts of the world, the polluted skies of Eastern Europe have created an ozone hole over Australia, environmental decisions of the large industrialized countries threaten to flood whole countries in the South Pacific, and conflicts in Europe and Africa become headline news in other countries.

On the education front, the international focus on student achievement, through student achievement tests such as TIMMS or PISA, allowed us to find out what was happening in other parts of the world. If we are to add to Beare's (1998) previous metaphors for education, we might suggest that we have moved through the pre-industrial, post-industrial and enterprise metaphors and the most recent S-curve might be considered the 'market' metaphor, where the idea of enterprise has been taken to its logical extent. Now the expectation is that if schools compete with each other for students and that parents are given choice as to which school to send their child to, that achievement levels will rise. This has led to a new understanding of accountability, based on choice and the market rather than cooperative achievement for everyone. The fourth S-curve led to a focus on accountability, for schools, for teachers, for school leaders and for the universities that educated them.

\section{The new accountability 'game'}

The data that is available to politicians and the public is now monumental. It is now possible, with the judicious use of the internet, to compare country with country, state with state within a particular country, districts or regions within a particular state, individual schools with other schools in a single district and eventually individual classrooms with other classrooms in a single 
school. Unfortunately, although we can establish differences between students based various social class and ethnic background data in these studies, the comparisons don't really take into account the circumstances students in different countries experience at school and the communities in which they live.

Recent international studies have compared and reported the performance of 'my' country with 'other' countries. These have included the Trends in International Mathematics and Science Study - TIMMS (1995, 1999, 2003) - see http://nces.ed.gov/timss/index.asp and also the more recent Program for International Student Achievement - PISA (2000, 2003, 2006), conducted by the Organization for Economic Co-operation and Development (OECD) - see http://www.pisa.oecd.org/. By 2009 87\% of the world's economy will be covered by PISA testing. PISA allows a comparison of some of the mean scores for reading, mathematics and science literacy for the data collected in 2006 (see table 1 below). The scores enable a comparison to be made between ourselves and the best performing countries in the study for the data provided. The table shows that a number of countries are above the OECD average for all three areas, and some perform much better than others.

Table 1: PISA (2006) Mean Scores for Reading, Mathematics and Science Literacy

\begin{tabular}{|l|l|l|l|l|l|}
\hline \multicolumn{2}{|c|}{ Reading } & \multicolumn{2}{c|}{ Mathematics } & \multicolumn{2}{c|}{ Science } \\
\hline Korea & 556 & Taipei & 549 & Finland & 563 \\
\hline Finland & 547 & Finland & 548 & Hong Kong & 542 \\
\hline Hong Kong & 536 & Hong Kong & 547 & Canada & 534 \\
\hline Canada & 527 & Korea & 547 & Taipei & 532 \\
\hline Japan & 522 & Netherlands & 531 & Estonia & 531 \\
\hline New Zealand & 521 & Switzerland & 530 & Japan & 531 \\
\hline Ireland & 517 & Canada & 527 & New Zealand & 530 \\
\hline Australia & 513 & Macao & 527 & Australia & 527 \\
\hline Liechtenstein & 510 & Liechtenstein & 536 & Netherlands & 525 \\
\hline Poland & 508 & Japan & 523 & Liechtenstein & 522 \\
\hline Sweden & 507 & New Zealand & 522 & Korea & 522 \\
\hline USA (2003) & 504 & USA & 489 & USA & 474 \\
\hline OECD Average & 492 & OECD Average & 498 & OECD Average & 500 \\
\hline
\end{tabular}


The PISA study not only provides a detailed analysis of science performance and student attitudes in 2006 (it was reading in 2000 and Mathematics in 2003), but also categorized students for all three areas into different levels, from level one being virtually unable to perform, to level five (or six) where students were able to manipulate knowledge at a high level of proficiency. Table 2 shows the percentages of students that are performing at the various levels of reading, literacy in 2006. Similar tables could also be developed for Science and Mathematics.

Table 2: Percentages of students at various levels of reading literacy (PISA, 2006)

\begin{tabular}{|l|c|c|c|c|c|c|c|}
\hline & Mean & $\begin{array}{c}\text { below } \\
\text { level 1 }\end{array}$ & $\begin{array}{c}\% \\
\text { level } \\
1\end{array}$ & $\begin{array}{c}\% \\
\text { level } \\
2\end{array}$ & $\begin{array}{c}\% \\
\text { level } \\
3\end{array}$ & $\begin{array}{c}\% \\
\text { level } \\
4\end{array}$ & $\begin{array}{c}\% \\
\text { level } \\
5\end{array}$ \\
\hline Korea & 556 & 1 & 4 & 13 & 27 & 33 & 24 \\
\hline Finland & 547 & 1 & 4 & 16 & 31 & 32 & 17 \\
\hline Hong Kong & 536 & 1 & 6 & 17 & 32 & 32 & 13 \\
\hline Canada & 527 & 3 & 8 & 18 & 30 & 27 & 15 \\
\hline New Zealand & 521 & 5 & 10 & 19 & 26 & 25 & 16 \\
\hline Ireland & 517 & 3 & 9 & 21 & 30 & 25 & 12 \\
\hline Australia & 513 & 4 & 10 & 21 & 30 & 25 & 11 \\
\hline Liechtenstein & 510 & 5 & 9 & 20 & 31 & 24 & 10 \\
\hline UK & 495 & 7 & 12 & 23 & 29 & 21 & 9 \\
\hline USA (2003) & $\mathbf{4 9 5}$ & $\mathbf{7}$ & $\mathbf{1 3}$ & $\mathbf{2 3}$ & $\mathbf{2 8}$ & $\mathbf{2 1}$ & $\mathbf{9}$ \\
\hline OECD Average & 492 & 7 & 13 & 23 & 28 & 21 & 9 \\
\hline
\end{tabular}

Because of a problem in printing the tests, the USA was unable to be given a score for its reading literacy in 2006, so the 2003 score has been used. Table 2 indicates that whereas the top countries have $40 \%$ or more of their students performing at the top two levels in reading, that the USA has only $30 \%$ doing so. Also, whereas the top nations have only around $6 \%$ of their students performing at the bottom two levels, USA has $20 \%$, or more than three times as many. Since there are in excess of 65 million students in the USA, this means there are approximately 13 million students who are incapable of doing anything more than the simplest tasks in reading. It is also clear that the United Kingdom is facing similar issues for its students. The same issues also 
exist for both Science and Mathematics in the USA and the UK where they both performed significantly more poorly than the top nations.

The use of these international comparisons has identified the need to maintain and improve the effectiveness and efficiency of what happens in schools for governments around the world. The fourth S-curve came from this challenge. Countries around the world were looking at what others were doing to try and change what they were doing in order to improve student achievement. Hong Kong took this to a new level, where they not only found out what others were doing but employed people from countries that they thought were doing it best to help them set up similar systems in their own country. This is the perfect example of what we might call thinking globally and acting locally. One of the outcomes of this form of development has been the international acceptance of the self-managing school as a mechanism for school improvement and the increasing use of a market approach to schooling as a mechanism for adjustment.

There is some evidence that student achievement is hard to shift, even after all of the reforms that have occurred in recent times. The National Assessment of Educational Progress (NAEP) Reading test scores have been virtually unchanged despite over forty years of educational reform efforts. There is some evidence that the gap between the socially advantaged and the socially disadvantaged has closed somewhat, but this has been confined to the elementary years of school. By the time students reach high school the level of performance is the same as it was in the 1970s. Despite all of the resources and reform efforts that have occurred since the 1980s after the Nation at Risk report, overall achievement is much the same as it has always been. It could be argued that we have not succeeded in our aspiration to ensure quality education for all.

There are many arguments made as to why this is the case and issues such as the changing population and demography in the United States are considered key issues, but other countries also have substantial migration intakes yet still perform much better than the USA. Canada, New Zealand and Australia all have substantially higher proportions of foreign born people in their communities and the Netherlands, Ireland and Sweden all have proportions similar to the USA. 
All of these countries perform substantially better in reading performance. It is also the case that while most other countries in the study are substantially smaller than the USA, there are countries, such as Japan, that have large populations, yet perform much better than the USA.

Perhaps the issue might be that the two factors interact. If you have a large AND diverse population, then it may be difficult to cope with the demands. It may also be the case that further analysis can establish where the migration comes from. So migrants to certain countries might come from countries that speak the same language as they do. This would make educating the population much easier. Other migrants may come from severely disadvantaged countries as a means of improving circumstances for their families. However, the distribution of wealth in countries, tells a different story. The proportion of wealth that is controlled by the top $10 \%$ of the population and the bottom $10 \%$ of the population in the USA is substantially different to other developed nations and the American economy is more similar to countries such as Turkey, Thailand and Brazil than it is to those of Finland, the Netherlands, Canada and Australia. So it is not necessarily the proportion of foreign born that is the key issue, but where those people come from. America for years has been the haven of people from less developed countries, to the point where America itself is now looking like a less-developed country, in terms of its economic activity and its educational achievements.

However, other countries have similar difficulties in raising the achievement bar. The Executive Summary of the 2006 PISA report (p 48) claims:

\section{It is now possible to track change in reading performance over a six-year period. The results suggest that, across the OECD area, reading performance has generally remained flat between PISA 2000 and PISA 2006. This needs to be seen in the context of significant rises in expenditure levels. Between 1995 and 2004 expenditure per primary and secondary student increased by $39 \%$ in real terms, on average across $O E C D$ countries.}

Thus despite the efforts that have been made, and the expenditure directed towards this, there has been little change in student achievement. 
So if we look at the history of the S-curve in education, the following trends emerge.

\begin{tabular}{|l|l|l|l|}
\hline Period & Focus of delivery & Those effectively educated & Dominant Paradigm \\
\hline 1000-1870 AD & Individual & Few People & $\begin{array}{l}\text { Thinking and acting } \\
\text { individually }\end{array}$ \\
\hline $1870-1980 \mathrm{AD}$ & Local & Some people & Thinking and acting locally \\
\hline 1980-2000 AD & National & Many People & $\begin{array}{l}\text { Thinking nationally and } \\
\text { acting locally }\end{array}$ \\
\hline $2000-2010 \mathrm{AD}$ & Global & Most People & $\begin{array}{l}\text { Thinking globally and acting } \\
\text { locally }\end{array}$ \\
\hline
\end{tabular}

The first trend is that how we think about education has changed quite substantially over the last thousand years, but that most of those changes have come in the last one hundred and fifty years, as indicated in the table above. Over the course of education's history, the focus of education changed from individual goals through local and national goals to international goals and the scope of education has moved from few people with any education at all to most people having a pretty effective education. We can ask ourselves, what challenges lie ahead? This challenge was been characterised (Townsend, 1998a: 248) as:

We have conquered the challenge of moving from a quality education system for a few people to having a quality education system for most people. Our challenge now is to move from having a quality education system for most people to having a quality education system for all people.

During this history we have moved from a time where we had individual teachers working with one or more students, through the development of classrooms, schools and school systems, to a time where national authorities have taken an interest in local school systems and where global comparisons have directed some of the policies promoted by those systems.

We have moved through what Beare called the Pre-Industrial, the Industrial and the PostIndustrial metaphors of education and we are currently in what I call the Accountability metaphor of education, where the market and choice programs have been put in place as a means of bludgeoning schools into conformity. What we see is that, like Future Shock (Toffler, 1971) 
argued, the times between the changes in S-curves have shrunk quite rapidly. If we look at the first S-curve lasting four or more thousand years, the second lasted a little over a hundred, the third just twenty and the fourth probably around ten. This means that we probably are on the edge of a fifth S-curve that will take us to a new way of thinking about education. Peter Drucker argued (1993: 209) that No other institution faces challenges as radical as those that will transform the school. This is likely to still be the case in the future as it could be argued that radical change has not yet taken place. Classrooms and schools are still more alike what they were a hundred years ago than they are different. So where might this lead?

Despite the rapid changes that have occurred in education over the past decade, the focus and scope of education must change once again. As far back as 1981 Minzey (1981) argued that previous educational reform had been similar to rearranging the toys in the toy box, when what we really needed was a whole new box. We now need to move to a new S-curve, where we close in on universal quality education, where every single student has a successful school experience.

Interestingly enough, to have this universal focus, every person on the globe must have the skills and attitudes necessary to take us to the next level of development. To really embrace this perspective, we must again focus on the individual, which is where education was when it started. The wheel has come a full circle, with the difference this time being that the scope now must be all people embraced by this form of education rather than just the few that was the case a thousand years ago. If we are to add to Beare's metaphors one more time, we might argue that the next S-curve will lead to a justice metaphor for education, where governments and societies accept that it is their responsibility to educate their populations to a high level and where we approach the human dream of a highly educated global population. Here, the recognition is that for true education to occur, we cannot have education for the few who are rich and privileged (pre-industrial), we cannot see schools as factories (post-industrial) or businesses (enterprise), and we cannot expect the market to solve our problems, but must see education as a community experience, where people work together for the betterment of themselves, each other, the local 
community and the planet as a whole. To do this the focus must become universal. All people must succeed. We are moving to a time of 'glocalization', which is 'the intersection of local and global concerns' and where 'every local action has a global component' (Hill 2006, as cited in Merriam, Courtenay and Cervero, 2006, p. 271). We have to move beyond thinking globally and acting locally to thinking and acting both locally and globally. This suggests that we have to do things in a different way, we have to move beyond accountability, which is simply a counting and sorting process, and seems to mostly have been designed to enable politicians to report things to communities in slick sound bites and with little or no analysis, and towards responsibility, where we need to respond to the needs and circumstances of the young people we serve and have an internal motivation to improve schools, not because it makes us look better, but because it is the right thing to do for the young people we interact with. Under these circumstances communities, and governments, accept that it is both their legal and moral responsibility to ensure that all people within their communities are given the educational provision required to enable them to achieve their full potential as global citizens.

If the S-curves from the start of education's history are progressively described then the progress of education over time can be documented in the following way. The next S-curve starts to become clear. 
Thinking and Acting Globally and Locally

Thinking Globally and Acting Locally

Thinking Nationally and Acting Locally

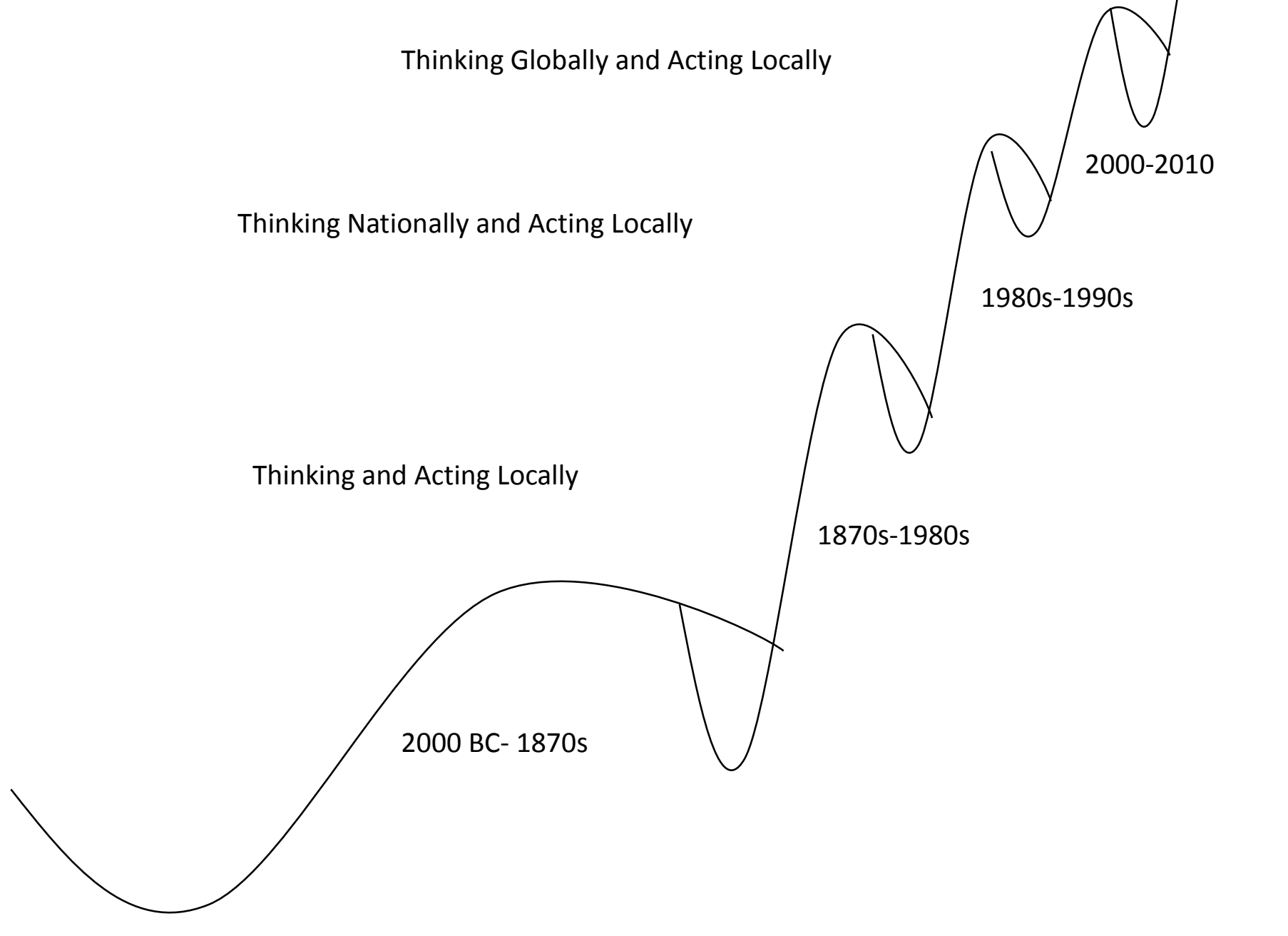

(1)

\section{Thinking and Acting Individually}

There are a number of implications for this shift from thinking globally and acting locally to thinking and acting both locally and globally. These implications occur at all levels of education endeavor, from the policy level, to the practice level and the training level. The policies need to guide a new way of thinking about and structuring education, both leadership and classroom practices need to change which leads to the need for both curriculum and pedagogical changes. In turn, this will lead to the need for new ways of educating both teachers and school leaders. If we 
start with the big picture, the table below suggests some tentative changes at both the policy level and the way in which schools are run.

\begin{tabular}{|c|c|c|}
\hline Thinking Globally & Acting Locally & $\begin{array}{l}\text { Thinking and Acting both } \\
\text { Locally and Globally }\end{array}$ \\
\hline \multicolumn{3}{|l|}{ For Education Policy } \\
\hline $\begin{array}{l}\text { Recognition that the world has } \\
\text { changed quite substantially } \\
\text { since the development of } \\
\text { schools. World's best practice } \\
\text { needs to be conducted if } \\
\text { education systems are to keep } \\
\text { up with these changes. }\end{array}$ & $\begin{array}{l}\text { Education systems use what } \\
\text { they have learned from other } \\
\text { systems, adapting what they } \\
\text { have learned to the local } \\
\text { circumstances. International } \\
\text { comparative data are used to } \\
\text { drive local school } \\
\text { improvement. }\end{array}$ & $\begin{array}{l}\text { There is a reassessment of the } \\
\text { purpose and delivery of } \\
\text { education in a rapidly } \\
\text { changing world. There is } \\
\text { recognition that education } \\
\text { need not be a competitive } \\
\text { process, but instead world's } \\
\text { best practice should be freely } \\
\text { shared for the benefit of all. } \\
\text { The available technology is } \\
\text { utilized to ensure that the } \\
\text { available knowledge and skill } \\
\text { is translated into practice. }\end{array}$ \\
\hline \multicolumn{3}{|l|}{ For the School Level } \\
\hline $\begin{array}{l}\text { Recognition that the level of } \\
\text { success of an individual } \\
\text { school is a complex mixture of } \\
\text { the characteristics of the } \\
\text { students, families and local } \\
\text { community on the one hand } \\
\text { and the skills, values and } \\
\text { development of the teachers } \\
\text { and school leaders. }\end{array}$ & $\begin{array}{l}\text { Self-managing systems of } \\
\text { education provide } \\
\text { opportunities for the } \\
\text { individual schools and their } \\
\text { communities to respond in } \\
\text { unique ways to the directives } \\
\text { and guidelines laid down by } \\
\text { the system. Schools compete } \\
\text { for students. }\end{array}$ & $\begin{array}{l}\text { Recognition that not all school } \\
\text { communities are able to } \\
\text { operate at the level required } \\
\text { for universal student success. } \\
\text { Systems establish mechanisms } \\
\text { where highly capable schools } \\
\text { and individuals provide } \\
\text { support to those less capable } \\
\text { as a means of improving the } \\
\text { system as a whole. }\end{array}$ \\
\hline
\end{tabular}

To establish this way of thinking we need to consider what I have called the Core-Plus

Curriculum (Townsend, 1994) which ensures that both:

The CORE areas, those areas identified by the state as being so important that every child should learn and know them, AND The PLUS areas, those areas identified by the school community as being important to their children, are given the time, attention and resources necessary for those skills, attitudes and knowledge to be planned for, learned and evaluated.

At the system level, this leads to an understanding that for us to be successful, we need to support all schools to be successful and, clearly, the market model does not subscribe to this understanding unless we adopt a new model of 'market' based on interest rather than financial 
ability to purchase 'quality'. An analogy might be the move from a market where we have a Rolls Royce level of education competing against the Volkswagen beetle, where the buyer purchases based on financial ability and prestige to a 'market' model where we have General Motors, Ford and Toyota mid-level cars, where the buyer will spend the same amount of money, but purchase their car of choice based on the variety of extras that they wish to have for the price. All buyers get a similar quality, but the specific content that they receive will be based on their particular preference for that aspect. At the school level, rather than hoarding best practice and using it to compete for more, or better students, schools would share best practice to ensure that communities would receive the quality of education that they need.

As well as changes at the policy levels, there also needs to be changes in what happens in the classroom, if we are to achieve our aim of universal success for all students. However, if young people's learning is the end goal, we need to reconsider what this means in a rapidly changing, globalized world. Wang, M.C., Haertel, G.D. and Walberg, H.J. (1993/1994, Educational Leadership, pp 74-79) analyzed 179 chapters, conducted 91 research syntheses, interviewed 61 educational researchers, considered 11,000 findings related to student learning. Twenty eight specific characteristics of a learning oriented school are grouped into 6 categories. The top five characteristics are listed in order of their importance to student learning:

1. Classroom Management

2. Metacognitive processes

3. Cognitive processes
4. Home Environment/Parental Support

5. Student/Teacher social interactions

If we look at these top five elements that contribute to student learning, it becomes obvious that it is what happens in the classroom, the home and the community that is critical to an individual student reaching his or her potential. The student's ability to learn, the way in which the classroom is organized and managed and the relationships between student, teacher and parent are the keys to learning. The past decade has seen massive changes at the state and school levels by various restructuring activities, but few that have tried to change what happens in classrooms. Yet as Ashenden (1994: 13) argues: 
The greatest single weakness in these reforms is that they stop at the classroom door. The classroom is the student's workplace. It is, in essence, a 19th-century workplace - much more humane and interesting but recognisably the same place. It is an inefficient and inequitable producer of the old basics and simply incompatible with the new.

If we are concerned about helping students to learn then, there are three major issues for educators. The first is having an appropriate curriculum for a rapidly changing world, the second is the pedagogy we use to engage every student in this curriculum and to enable them to build a positive relationship to learning, so that they can become a lifelong learner, and the third is the way in which we assess the level of success. The table below provides some indicators of where we are now and where we might want to be.

\begin{tabular}{|c|c|c|}
\hline Thinking Globally & Acting Locally & $\begin{array}{l}\text { Thinking and Acting both } \\
\text { Locally and Globally }\end{array}$ \\
\hline \multicolumn{3}{|l|}{ For Curriculum } \\
\hline $\begin{array}{l}\text { Recognition that in the } \\
\text { international market, students } \\
\text { need to have high levels of } \\
\text { education in order to be } \\
\text { successfully employed. All } \\
\text { students should complete a } \\
\text { full school program. }\end{array}$ & $\begin{array}{l}\text { Strong focus on those } \\
\text { elements of curriculum } \\
\text { associated with preparing } \\
\text { them for further education, } \\
\text { including the basic skills and a } \\
\text { set of socially acceptable } \\
\text { values. }\end{array}$ & $\begin{array}{l}\text { Recognition that not all } \\
\text { students will go on to } \\
\text { university and that other skills } \\
\text { are necessary for those that } \\
\text { will not. As well as the } \\
\text { academic program, schools } \\
\text { will cater for those who wish } \\
\text { to go into the world of work or } \\
\text { other types of activity. }\end{array}$ \\
\hline \multicolumn{3}{|l|}{ For Pedagogy } \\
\hline $\begin{array}{l}\text { Classroom effectiveness is } \\
\text { more important than school } \\
\text { effectiveness when it comes to } \\
\text { student achievement. Better } \\
\text { qualified and more committed } \\
\text { teachers lead to higher levels } \\
\text { of student achievement. }\end{array}$ & $\begin{array}{l}\text { Strong focus on teaching to } \\
\text { the test, especially for students } \\
\text { who are struggling. Most } \\
\text { teacher professional } \\
\text { development focuses on basic } \\
\text { skills and 'proven techniques' } \\
\text { of imparting them. }\end{array}$ & $\begin{array}{l}\text { Recognition that a recipe } \\
\text { approach to teaching will not } \\
\text { lead to success for all students. } \\
\text { Teachers are given the skills to } \\
\text { build strong relationships with } \\
\text { students and making the } \\
\text { curriculum relevant through a } \\
\text { variety of different teaching } \\
\text { techniques. }\end{array}$ \\
\hline Thinking Globally & Acti & $\begin{array}{l}\text { nd Acting both } \\
\text { d Globally }\end{array}$ \\
\hline \multicolumn{3}{|l|}{ For Assessment } \\
\hline $\begin{array}{l}\text { Recognition that being } \\
\text { internationally competitive } \\
\text { involves understanding how } \\
\text { well students are learning in } \\
\text { comparison to others, both } \\
\text { locally and globally. }\end{array}$ & $\begin{array}{l}\text { Strong focus on those } \\
\text { elements of the curriculum } \\
\text { that are easily measured and } \\
\text { are likely to be part of an } \\
\text { international testing program. } \\
\text { This has led to a higher value } \\
\text { being given to some subjects }\end{array}$ & $\begin{array}{l}\text { Recognition that to be a fully } \\
\text { functioning human being takes } \\
\text { more than a particular score on } \\
\text { a standardized test. As well as } \\
\text { 'valuing what we measure' } \\
\text { steps are take to ensure that } \\
\text { we learn to measure other }\end{array}$ \\
\hline
\end{tabular}




\begin{tabular}{|l|l|l|}
\hline & than to others. & $\begin{array}{l}\text { human skills that are equally } \\
\text { valued. }\end{array}$ \\
\hline
\end{tabular}

We wonder why many young people fail to see the relevance of what they are taught, why they become difficult to teach and why they drop out. The truth of the matter is that students are not any more or less involved with the curriculum than their parents were. The curriculum of today is perhaps no more or less relevant than it was when their parents went to school, but in their parents' time people were able to get jobs that didn't require high qualifications; jobs in banks, in factories, on the land. Now those jobs are limited or non-existent and the jobs that are available to those who drop out have very limited economic earning potential. Perhaps it is time for us to refocus our attention as to what the curriculum is intended to do.

The curriculum in the USA is similar to perhaps $90 \%$ of subject areas in the curriculum in China, in South Africa, in Australia, the UK and Fiji. Not only is it similar now, but it always has been. It would seem to me that perhaps we should consider having a curriculum that, for at least fifty per cent of the time, focuses on what makes us human, that is, the human skills that are common to people no matter where they live. This could be could be considered the global curriculum, because it would be equally relevant to students, no matter where they lived. Perhaps twenty per cent of the time the curriculum should focus on what makes us American, or Australian or Chinese, our history, our geography, our political systems, which wouldn't change much over time. Thirty per cent of the time focuses on the specific content that is important to us at the time, the content knowledge that helps us to become employable, that prepares us for university, and so on. This content would change as times change, with the introduction of computer studies being the perfect example. By thinking and acting locally and globally, countries could work together to determine what will happen for the human skills part of the curriculum, countries could help states or districts determine what happens nationally and local communities could be involved in the development of the more immediate knowledge. The 
duplication of effort that we have in education at the moment would be removed and the resources saved could be directed to where learning actually occurs, in classrooms and for students. We might have to review the content curriculum on a regular basis, the national curriculum perhaps once in a while and the global curriculum hardly ever. Currently, and in the past, schools have taught content, and hoped that the human skills have been developed. What I am proposing here is that we focus on the development of human skills and we use the content to frame this discussion.

In our book Global Classrooms: Strategies for Engaging Students in Third Millennium Schools (Townsend and Otero, 1999), George Otero and I discuss the starting point for such a global curriculum. We argue that an education charter for the Third Millennium should be based upon four pillars:

- Education for survival (once the whole curriculum, now the building block for everything else);

- Understanding our place in the world (how my own particular talents can be developed and used);

- Understanding community (how I and others are connected); and

- Understanding our personal responsibility (understanding that being a member of the world community carries responsibilities as well as rights).

These four pillars join to create a new set of critical learning elements, a set of Third Millennium skills and attitudes. The rationale is the argument that to improve student achievement in standardized tests, we have to spend less time focusing on the tests and more time focusing on increasing learning capability in the student.

In some respects it is building a positive relationship to learning that is most important, after all, students will spend less than $3 \%$ of their lifetime in school. It might also be argued that under the current system of accountability, with structured curriculum based on specific standards and the continuous testing of student knowledge of that curriculum, building a positive relationship to learning is the thing we spend the least 
time on. We now know a great deal about learning and how teachers might need to behave to engage students. We also know that students will learn much better if they have their parents and the community actively supporting them and the schools in which they learn.

Increasing student engagement also involves changing our focus from curriculum to people. This refocusing means moving from the current situation where many students are isolated learners, learning the facts until the exam is over and then forgetting them forever, to becoming global self-regulated learners (Otero and Sparks, 2000), where instead of needing teachers, the students need someone able to help them construct their learning environment. The rationale for this is that I can only be successful as a teacher if my students learn. If my students are not learning then what can I say about myself as a teacher?

Research (Townsend, 2002) has shown that there is a strong relationship between the concepts that students have, of school, of teacher, of self, of learning and of future, and their performance in school. The underlying assumptions revolve around the use of either habitual or intelligent behavior. Habitual behavior occurs when a person picks up the 'vibes' that he senses in the environment, then habitually responds in the same way that he has previously. It is a simple matter of stimulus-response without thought. The brain research tells us if we respond to a particular stimulus in a particular way, there is a greater tendency to do the same thing the next time that stimulus appears. We become habitually responsive. The emotional response to the stimulus depends on how we see ourselves and the world outside and this can become predominantly positive (optimist) or predominantly negative (pessimist). An optimistic student can deal with or withstand the infrequent negative things that happen, but a pessimistic student sees things as just one more issue sent to trouble them.

However, with intelligent behaviour there has been a thoughtful response to the environment. In this instance, the student has been taught to reinterpret, or determine, the environment and the 
subsequent perceptions, emotions and actions, by asking appropriate questions that support and strengthen them, even in situations that might initially be interpreted as threatening. Clinch (2003) argues that to make every student a strong, positive learner we need to develop five positive concepts, learning, teacher, self, school and future. If we can train teachers to develop these concepts, then we have a good chance of increasing student achievement. Of these, learning and future are most critical, since future is our hope for ourselves and those around us and learning is the way in which we achieve our desired future.

As Hill argued (1998) ...one of the more powerful conclusions arising from recent research is that much of the variation between schools is, in fact, due to variation among classes. So if we are to move towards a more effective school system, it happens by promoting more effective schools. If we are to support the development of more effective schools, it will be through the promotion of more effective classrooms. If we are to adopt the curriculum and pedagogical arguments above, we also need to come up with a new form of measuring the progress of our students. Perhaps the starting point of this exercise could be to ask ourselves the question, 'Apart from the academic outcomes, what skills, values and attitudes do we want every student to have by the time they leave this school?' Each school community could come up with their own list, which could be added to those created by both education systems and even nations. Many of these are in existence in policy papers already but few if any of them have been acted on. The other steps involved would include asking ourselves what behaviors are demonstrated by people who are skilled in this activity and what activities could be included in the curriculum that would enable students to demonstrate these behaviors. The final issue would be how we might assess the success levels of students and how we might report this to both parents and authorities. In this way we could move towards Ainscow's (2005) proposal of 'We need to move from valuing what we measure to measuring what we value'.

If we accept the premise that to improve student achievement, changes must be made in curriculum, engagement and relationships, and measuring success, then perhaps the greatest task 
in the future is to manage the changes that are necessary in the hearts and minds of teachers, since it is here that true improvement in student learning lies. We must move individual teachers past competence and into a position of capability. Cairns (1998: 1) argued 'Modern Teachers need to be developed as capable which is seen as moving 'beyond' initial competencies. The Capable Teacher is what we should be seeking to develop, encourage and honor as the hallmark of our profession.'

Making teachers more flexible, adaptable and professional becomes a challenge for school leaders. The model for developing capable teachers is a combination of three intertwined elements:

- Ability (describes both competence and capacity)

- Values (the ideals that govern the use of ability)

- Self-efficacy (the way people judge their capability to carry out actions effectively)

The challenge becomes clear. To improve teachers' abilities we need to focus our attention on their professional development, particularly in the areas identified above; to improve teachers' values we need to focus on developing and passing on a notion of values and teacher professionalism; and to improve teachers' self-efficacy we need to provide teachers with the ability to believe in themselves. Just as we need to change the beliefs and understandings of students if we want them to improve their level of learning, school leaders need to change the beliefs and understandings of teachers to manage this process. Essentially for every student to improve their level of achievement, then every teacher must believe that every student has the capability to learn and must have the understanding of how best to promote that. It is one or the other of these two factors that seems to be missing for many teachers and is currently curtailing changes in student achievement. The leadership imperative of the future, is to move towards a universal set of beliefs and understandings on the part of teachers that will lead to positive outcomes and relationships for every student.

\section{School Leadership}


Finally, if we are to be successful in our attempt to achieve universal student success, then we also need to rethink the way in which school leaders do their business and as a consequence of this, how school leaders themselves are trained in the future. The table below provides some tentative first thoughts on these issues.

\begin{tabular}{|c|c|c|}
\hline Thinking Globally & Acting Locally & $\begin{array}{l}\text { Thinking and Acting both } \\
\text { Locally and Globally }\end{array}$ \\
\hline \multicolumn{3}{|l|}{ For Educational Leadership } \\
\hline $\begin{array}{l}\text { International recognition that } \\
\text { the role of the school leader is } \\
\text { becoming increasingly } \\
\text { important in establishing the } \\
\text { conditions of high levels of } \\
\text { student learning. }\end{array}$ & $\begin{array}{l}\text { Strong focus on those } \\
\text { elements of management that } \\
\text { promote instructional } \\
\text { leadership, including the need } \\
\text { to understand the law, finance, } \\
\text { policy, data analysis and } \\
\text { personnel development. }\end{array}$ & $\begin{array}{l}\text { Recognition that an } \\
\text { outstanding leader relies upon } \\
\text { the people that he works with } \\
\text { and that managing the school } \\
\text { can only be successful if team } \\
\text { leadership and relationship } \\
\text { skills are also developed. }\end{array}$ \\
\hline \multicolumn{3}{|l|}{ For Leadership Preparation } \\
\hline $\begin{array}{l}\text { Recognition that the job of } \\
\text { school leader is now too } \\
\text { complex and difficult for a } \\
\text { single person to achieve. } \\
\text { There are now a number of } \\
\text { international research } \\
\text { activities comparing school } \\
\text { leadership in various } \\
\text { countries. }\end{array}$ & $\begin{array}{l}\text { Formal educational leadership } \\
\text { preparation programs focus on } \\
\text { developing school leaders that } \\
\text { are capable of operating } \\
\text { within the school system that } \\
\text { trains them. Training is mostly } \\
\text { associated with preparing } \\
\text { formal school leaders that } \\
\text { manage their schools and the } \\
\text { operations within them. }\end{array}$ & $\begin{array}{l}\text { School leadership programs } \\
\text { offer opportunities for a range } \\
\text { of leadership development } \\
\text { activity from junior staff to } \\
\text { senior leaders in an effort to } \\
\text { both spread the responsibility } \\
\text { for leading the school and to } \\
\text { establish a succession } \\
\text { planning model in schools. }\end{array}$ \\
\hline
\end{tabular}

Both of these issues point to a more complex approach to school leadership than just 'managing' schools. Bogotch and Townsend (forthcoming, p. 1) argue that true leadership is artistry and they characterize this as the place where the 'what' and the 'how' of school leadership come together.

The 'what' in this instance is the knowledge required to do the job well. It is 'knowing' about curriculum, about management, about human relations and about the various factors, both inside and outside the school, that are required to keep those within the school, students, teachers and others, safe and productive. However, it is only when this 'knowing' is joined by the 'how' that school leadership is successful. The 'how' in this instance is the set of processes used by the school leader to communicate, implement, evaluate and relate the knowledge base to those with whom the leader interacts, together with the attitudes and values that are shared between both leader and followers. We would argue that the practice of educational leadership is artistry, when these two factors come together in a way that promotes both simultaneously. 
Townsend and Bogotch (forthcoming) later argue:

...that when state mandates, educational laws, leadership standards, ministerial pronouncements, curricular designs and professional development programs are presented as ready-made answers to be delivered by school administrators to teachers and students that we are failing to make education come alive in ourselves and in others. We are not advocating for any specific 'what' or any specific 'how, 'but rather we are calling for the explicit integration of the what and the how in terms of developing educational theories and practices.

They use two case studies, one from Florida, USA and one from Victoria, Australia to demonstrate how different places focus on different forms of leadership for their schools. Florida is an example of what Elmore argues $(2007, \mathrm{p} 2)$ is a system that creates problems in terms of student achievement.

[In] ... state accountability systems in the U.S. and the U.S. national policy (No Child Left Behind), accountability for performance is considered to be the leading instrument of policy and human investment is considered to be a collateral responsibility of states and localities, which can be exercised according to their preference. In the U.S.... this situation has resulted in a disastrous gap between capacity and performance - the states and the federal government exert increasing pressure on schools to perform, but have essentially defaulted on their responsibility for human investment, leading to an increasingly large number of low-performing schools that continue to operate at low capacity.

In Florida, Townsend and Bogotch (forthcoming) report on the changing structure of the Florida

Educational Leadership Examination (FELE), which all school leaders must pass to gain

certification and thus directs the activities of leadership preparation programs.

Of the 91 specific skills identified as part of the new statewide FELE examination, 44 of them (48\%) refer to a knowledge and understanding of state or federal legislature. Of the 16 skills that are identified under the standard of Managing the Learning Environment, 15 refer to state legislation or standards and of the 13 skills related to Human Resource Development, 12 refer to Federal or state laws or regulations. All 4 of the ethical leadership skills do the same. Clearly, an ethical leader is one that obeys the local rules. Four of the 6 skills related to Community School Partnerships can likewise be accomplished through memorizing state statutes.

It is telling that all of the skills under Vision focus more on communication of the vision than actually developing one, that the two skills under Diversity involve following the law and state communications and that only two skills under Decision-Making Strategies make any mention of leadership at all. 
On the other hand, in Victoria, Elmore (2007:02) argues that one of the things that 'distinguishes the Victorian approach among its peers, is the presence of a strategic view of school improvement'. Another is its focus on capacity building.

From the ministerial level, through the department level, to the operating level of the public schools office, into the regions and then into the schools, there is broad agreement on the essential message that the strategy is fundamentally about investing in the knowledge and skill of people.

In Florida, the focus is firmly on the 'what' of school leadership. Victoria, on the other hand, has gone some way to not only consider the 'what' but also to focus on the people issues, the 'how' of school leadership.

The real issue for school leaders is how to manage our schools, our staff, our resources and our programs in a time of complex change. Transactional leadership, where the leader manages others towards a common (or sometimes not common) goal, was typical of the form of management in the 1980s during the time when there was the transition between the second and the third s-curve. By the time the third s-curve was at its peak, transformational leadership was being proposed as a method of leading schools (see for instance, Leithwood and Jantzi, 1990; Leithwood, 1992) and this involved a new set of emotions and a new set of strategies. The last few years however, in a number of places, we have seen a reversion to more transactional approaches as the decision-making capabilities of principals at the local level have been overtaken by decisions being made by national, state or local politicians or governments. The political nature of education has never been more obvious. But as Zenger, Musselwhite et al (1994) argue, moving from supervisory leadership through participative leadership to team leadership involves different activities on the part of the leader. Teachers have a wide range of emotions about recent educational change and they can articulate specific reasons why those particular feelings have emerged. Using these interactions with teachers as a basis, a model for 
managing complex human change has been proposed. The model (see attachment 1) is underpinned by the belief that, in order to improve relationships between students and teachers, teachers and administrators, and teachers and the wider community, leaders must recognize that they are dealing with situations that involve complex human interactions. This may need to be handled differently to changes in business organizations, where the bottom line of profit is much more easily identified than determining what should be the outcomes of student learning. Thus, to change complex human systems, leaders in human service agencies need to work in ways that elicit other emotions from their staff as well. Without these being in place negative feelings of various kinds start to occur.

Making teachers flexible, adaptable and professional becomes a challenge for all school leaders. To do this we need to provide what Southworth (2000) calls the nutrients for a productive teacher culture:

- being valued

- being encouraged

- being noticed

- being trusted

- being listened to

- being respected

The success, or otherwise of the task ahead of us will depend on our ability to build a school environment where the nutrients are maximized every day. We can start by promising to ourselves that in the next week I will value at least one teacher, I will encourage at least one teacher, and so on. But we also need to have teachers understand that they must be involved in the activity too. They too, should value, encourage, notice, trust, listen to and respect the people they work with...other teachers, parents, students and school administrators. If this can happen, the future of education will be made more positive than it is now. The building of relationships will become the leader's role in the school of tomorrow. In order to do this we need to know how people feel. 
The way in which school leaders go about their task will be critical to the way in which schools develop in the future. There are three dimensions to human relationships, the way in which we interact, the content of the interaction and the circumstances in which the interaction occurs (see appendix 2). The interaction can occur by one person either asking the other one something, or alternatively telling them something. The interaction can be about individual facts or pieces of information or it can be about the broader processes or concepts we use as human beings, and it can be either in a supportive atmosphere or an oppositional atmosphere. The situation is usually instigated in educational circumstances by the person in a powerful position. It might be the principal working with a teacher or it might be a teacher working with a student. Depending on the circumstances of the initial action, the reaction by the other person will follow.

The table below provides tentative breakdown of the types of interactions that can be initiated and the responses that are likely to emerge from that interaction. It is likely that a school leader will spend some of their time in each of these different situations over the course of a school week (and so will teachers with their students). So for instance, if the principal tells a teacher what to do in a confrontational way and the task is something very specific, then all the teacher gets to do is memorize the task and the principal is made happy. There may be times when this is appropriate, where for instance the teacher has failed to comply with a very specific departmental regulation. From another perspective, if the principal asks the teacher questions about ways in which processes or concepts associated with the teaching task and provides the teacher with support and feedback to assist them, then the likely outcome will be a better understanding by the teacher of how to do their job.

Over time, if the majority of successive interactions by the principal uses one or the other of these methods, then the brain research tells us that the likely response from teachers will become habitual. In the long term, when a person is consistently told what to do, where the knowledge base is very limited or specific and the environment of the interaction is negative or confrontational, the likely outcome is, at the worst, insubordination of some kind, and at the best, 
defiant compliance. Alternatively, if a leader spends a lot of their time asking questions about issues related to changing processes or developing people's concepts of what is possible, in a supportive environment, the longer term outcome will be cooperative learning and positive progress in their school.

\begin{tabular}{|l|l|l|l|}
\hline Management & $\begin{array}{l}\text { Leadership } \\
\text { approach }\end{array}$ & Content Focus & Teacher Response \\
\hline Leader asking & Leader supporting & Focus on concepts/processes & Understanding \\
\hline Leader asking & Leader supporting & Focus on facts/tasks & Knowledge \\
\hline Leader asking & Leader managing & Focus on concepts/processes & Self-doubt \\
\hline Leader asking & Leader managing & Focus on facts/tasks & Guilt \\
\hline Leader telling & Leader supporting & Focus on concepts/processes & Self-belief \\
\hline Leader telling & Leader supporting & Focus on facts/tasks & Clarity \\
\hline Leader telling & Leader managing & Focus on concepts/processes & Unquestioned belief \\
\hline Leader telling & Leader managing & Focus on facts/tasks & Memorization \\
\hline
\end{tabular}

If we are to move to the next level of performance in education, where all people involved in the activity become learners, then we will have to start thinking and acting in a different way. We need to recognize that education is essentially a human activity and to do it successfully we need to develop those crucial human skills that have helped mankind, over the centuries, to progress to higher levels. When we think of what we have accomplished over the centuries in human development, we have to ask ourselves the question: 'Why haven't we achieved universal human success in education?' Edison made the comment when asked about his conquering of the electric bulb: It was not that I failed 99 times, it was just that I found 99 ways of not making it work. His perspective was one that we need to adopt. We have learned so many ways in which some people can be successful, we need to keep searching for that one way where everyone can be. It is all a matter of perspective.

\section{References}

Ainscow, M. (2005) 'The Next Big Challenge: Inclusive School Improvement'. A keynote address to the International Congress for School Effectiveness and Improvement, Barcelona, Spain, January, 2005) 
Ashenden, Dean (1994) 'An Odd Couple? Social Justice. Performance Indicators.' A public lecture sponsored by the Victorian State Board of Education, Melbourne, Australia.

Beare, H. (1998) 'Enterprise: The new Metaphor for Schooling in a Post-Industrial Society' in Townsend, T. The Primary School in Changing Times: The Australian Experience, London and New York: Routledge.

Bogotch, I. and Townsend, T (in press) 'What are the essential leadership questions in a rapidly changing world?' in Townsend, T. and Bogotch, I. The Elusive What and the Problematic How: The Essential Leadership Questions for School Leaders and Educational Researchers, Sense Publishers, Rotterdam and Taiwan

Cairns, L. (1998) 'The capable teacher: The challenge for the $21^{\text {st }}$ Century'. Paper presented at the $28^{\text {th }}$ Annual Conference, Australian Teacher Education Association, Melbourne.

Clinch, R (2001) Secret Kids' Business, Melbourne, Hawker-Brownlow.

Drucker, Peter F. (1993) The ecological vision: reflections on the American condition New Brunswick, N.J. Transaction Publishers.

Elmore, R. (2007) Educational Improvement in Victoria. Melbourne, Victoria: Office for Government School Education, Department of Education.

Hill, P.W. (1998) 'Shaking the foundations: Research driven school reform' in School Effectiveness and School Improvement 9 (4) pp 419-436.

Leithwood, K.A. (1992, October). The move toward transformational leadership. Educational leadership, 8-12

Leithwood, K and Jantzi, D. (1990) Transformational Leadership: How Principals Can Help School Cultures." Paper presented at annual meeting of the Canadian Association for Curriculum Studies (Victoria, British Columbia, June).

Merriam, B. Courtenay, \& R. Cervero,(Eds.), Global issues and adult education: Perspectives from Latin America, Southern Africa, and the United States San Francisco, CA: Jossey Bass.

Minzey, J.D. (1981) Community Education and Community Schools. An address at the State College of Victoria, Frankston, Australia.

National Commission on Excellence in Education, (1983) A Nation At Risk: the Imperative for Educational Reform, Washington, D.C.: U.S. Government Printing Office.

Otero, G. Chambers-Otero, S. and Sparks, R. (2000) RelationaLearning, Melbourne, Hawker Brownlow.

Phillips, W. (2008) 'The "S" Curve' at http://www.qm2.org/mbriefs/scurve.html: downloaded July 23rd 2008

PISA (2006) Science Competencies for Tomorrow's World, Paris, OECD

Rogers. E.M. (1962/2003) Diffusion of Innovations. The Free Press

Southworth, G. (2000) 'Leading and Improved Pedagogy: International Perspectives'. A keynote paper presented at the PDN School Leaders Conference, Surfers Paradise, July. http://www.pdn.asn.au/confs/2000/2000.htm

Toffler, A. (1971) Future Shock, London, Pan.

Townsend, T. (1994) Effective Schooling for the Community, (London and New York: Routledge).

Townsend, T. (1998) 'The Primary School of the Future: Third World or Third Millennium?' in Townsend, T. The Primary School in Changing Times: The Australian Experience, London and New York: Routledge.

Townsend, T. (2002) The Impact of Radical intervention on the attitude and achievement of school refusers, Melbourne, Myer Foundation

Townsend, T and Bogotch, I. (in press) 'Change Over Time: From Knowing to Doing' in Townsend, T. and Bogotch, I. The Elusive What and the Problematic How: The Essential Leadership Questions for School Leaders and Educational Researchers, Sense Publishers, Rotterdam and Taiwan 
Townsend, T. and Otero, G. (1999) The global classroom: Engaging students in Third Millennium Schools, Melbourne, Hawker Brownlow.

Wang, M.C., Haertel, G.D. and Walberg, H.J. (1993/1994) ‘What helps students learn?' Educational Leadership, Winter, 1993/94, pp 74-79)

Zenger, J.H., Musselwhite, Ed., Hurson, K. \& Perrin, C. (1994). Leading Teams: Mastering the New Role. Burr Ridge, Illinois: Irwin. 


\section{Appendix 1}

\section{Managing Complex Human Change - From Transactions to Teams}

\begin{tabular}{|c|c|c|c|c|c|c|c|c|c|c|c|c|c|c|c|}
\hline \multicolumn{5}{|c|}{ The transactional leader } & \multicolumn{11}{|c|}{ The transformational or team leader } \\
\hline purpose & knowledge & support & resources & progress & participation & consideration & humor & excitement & passion & trust & compassion & equity & integrity & satisfaction & change \\
\hline & knowledge & support & resources & progress & participation & consideration & humor & excitement & passion & trust & compassion & equity & integrity & satisfaction & confusion \\
\hline purpose & & support & resources & progress & participation & consideration & humor & excitement & passion & trust & compassion & equity & integrity & satisfaction & anxiety \\
\hline purpose & knowledge & & resources & progress & participation & consideration & humor & excitement & passion & trust & compassion & equity & integrity & satisfaction & resistance \\
\hline purpose & knowledge & support & & progress & participation & consideration & humor & excitement & passion & trust & compassion & equity & integrity & satisfaction & stress \\
\hline purpose & knowledge & support & resources & & participation & consideration & humor & excitement & passion & trust & compassion & equity & integrity & satisfaction & hesitation \\
\hline purpose & knowledge & support & resources & progress & & consideration & humor & excitement & passion & trust & compassion & equity & integrity & satisfaction & exclusion \\
\hline purpose & knowledge & support & resources & progress & participation & & humor & excitement & passion & trust & compassion & equity & integrity & satisfaction & anger \\
\hline purpose & knowledge & support & resources & progress & participation & consideration & & excitement & passion & trust & compassion & equity & integrity & satisfaction & boredom \\
\hline purpose & knowledge & support & resources & progress & participation & consideration & humor & & passion & trust & compassion & equity & integrity & satisfaction & agitation \\
\hline purpose & knowledge & support & resources & progress & participation & consideration & humor & excitement & & trust & compassion & equity & integrity & satisfaction & apathy \\
\hline purpose & knowledge & support & resources & progress & participation & consideration & humor & excitement & passion & & compassion & equity & integrity & satisfaction & $\begin{array}{l}\text { guilt } \\
\end{array}$ \\
\hline purpose & knowledge & support & resources & progress & participation & consideration & humor & excitement & passion & trust & & equity & integrity & satisfaction & fear \\
\hline purpose & knowledge & support & resources & progress & participation & consideration & humor & excitement & passion & trust & compassion & & integrity & satisfaction & patronage \\
\hline purpose & knowledge & support & resources & progress & participation & consideration & humor & excitement & passion & trust & compassion & equity & & satisfaction & suspicion \\
\hline purpose & knowledge & support & resources & progress & participation & consideration & humor & excitement & passion & trust & compassion & equity & integrity & & frustration \\
\hline
\end{tabular}

(C) Tony Townsend

Dept of Educational Studies, University of Glasgow 
Appendix 2 


\section{Leader Behaviors and Teacher Responses}

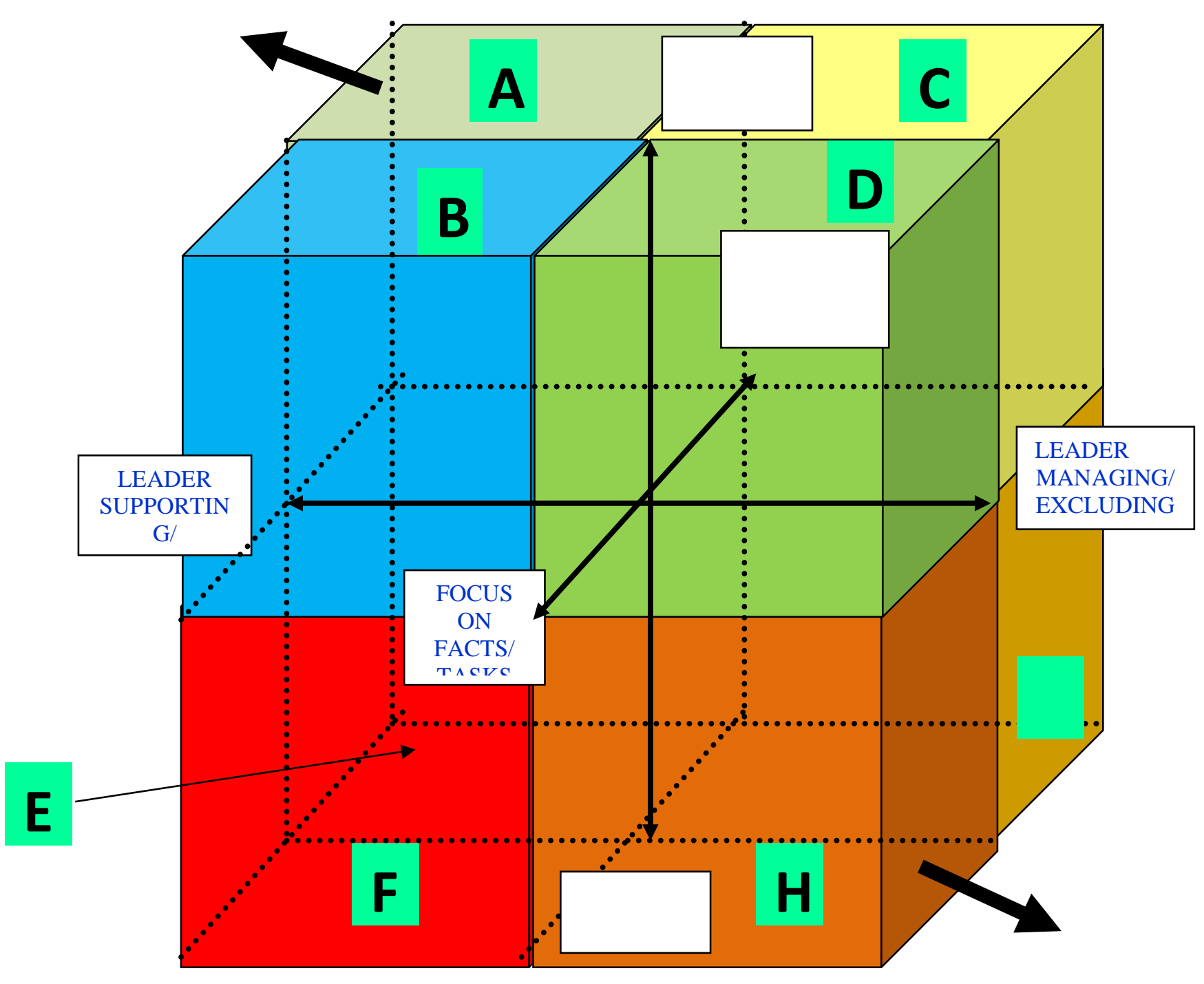


